\title{
Project scheduling and buffer management: A comprehensive review and future directions
}

\author{
Shakib Zohrehvandi ${ }^{a^{*}}$ and Roya Soltani ${ }^{b}$
}

${ }^{a}$ New Technologies department, Center for European Studies, Kharazmi University, Tehran, Iran

${ }^{b}$ Department of Industrial Engineering, KHATAM University, Tehran, Iran

\section{H R O N I C L E}

Article history:

Received: June 17, 2021

Received in revised format: July 30, 2021

Accepted: September 18, 2021

Available online:

September 18, 2021

Keywords:

Project buffer management

Buffer sizing

Buffer consumption monitoring

Project time/resource optimiza-

tion

\section{A B S T R A C T}

\begin{abstract}
In the project management, buffers are considered to handle uncertainties that lead to changes in project scheduling which in turn causes project delivery delay. The purpose of this survey is to discuss the state of the art on models and methods for project buffer management and time optimization of construction projects and manufacturing industries. There are not literally any surveys which review the literature of project buffer management and time optimization. This research adds to the previous literature surveys and focuses mainly on papers after 2014 but with a quick review on previous works. This research investigates the literature from project buffer sizing, project buffer consumption monitoring and project time/resource optimization perspectives.
\end{abstract}

(C) 2022 Growing Science Ltd. All rights reserved.

\section{Introduction}

Today, one of the biggest problems that companies, and organizations are faced with is that their projects take longer than the scheduled duration. Projects are often prolonged, lots of delays happen during the execution phase, and most of the time projects do not finish according to planned schedule. An effective method to improve the stability of project scheduling is to consider buffers to cope with time changes of projects using the critical chain method. In fact, a project buffer which does not have any float is considered at the end of a critical chain to be used when there is a delay. To increase safety in project implementation and factories production in the face of possible and unpredictable events, time buffers will be placed in different parts of projects and activities to prevent the negative effects of fluctuations in activities on the project's critical chain which will otherwise lead to a delay in the whole project. Three types of buffers are used, called the Project Buffer, Feeding Buffer, and Resource Buffer (Vanhoucke et al., 2016). The project buffer is placed at the end of the project's critical chain to maintain the project delivery date (Goldratt, 1997). Buffer management can be considered as the most important measure in implementing the critical chain scheduling, because if short buffers are allotted, we will need to re-schedule the project repeatedly until the end of the project, and if long buffers are allotted, all concepts used in scheduling will be violated (Zohrehvandi et al., 2020). According to an extensive study by Hall (2015), project scheduling and project buffer management are among research areas with a high research potential for the next 10 years. Critical chain project management (CCPM) technique improves the accuracy of project plans by addressing variations by considering buffers in the project schedule. CCPM was originally proposed by Goldratt (1997) to improve the traditional methods of project management using a new mechanism to manage uncertainties. The Theory of Constraints (TOC) and the critical chain/buffer management

* Corresponding author.

E-mail address: shakibzohrevandi@gmail.com (S. Zohrehvandi) 
are two effective approaches in project management (Goldratt, 1984). Since the introduction of the TOC, several researchers have examined its application in project management (e.g., Newbold (1998), Herroelen and Leus (2001), Leach (2005), Tukel et al. (2006), Woeppel (2006), Rabbani et al. (2007), Blackstone et al. (2009)). Project buffers and feeding buffers aggregate the protection (by removing safety from the individual tasks) that a project needs to meet its due date and allow focus on project duration (Leach, 2005) .To deliver a project within the shortest possible time, several project planning and scheduling techniques such as CCPM can typically be used in project implementation (Li et al, 2019). CCPM technique identifies the longest chain of both precedence and resource dependent tasks in the generated project schedule as the critical chain of project network schedule. CCPM is based on methods and algorithms derived from TOC. Most traditional methods of buffer sizing such as root square error method (RSEM), cut and paste method (C\&PM), adaptive procedure with resource tightness (APRT), and adaptive procedure with density (APD) do not yield realistic buffer estimations under resource constraints (Vanhoucke, 2016). To improve this problem, it's better to hybrid these methods with other scheduling methods or design a new project buffer management algorithm/model. As mentioned before, there are not literally any surveys which review the literature of project buffer management and time optimization. In this paper, project buffer management is investigated from the following perspectives: project buffer sizing, project buffer consumption monitoring, project buffer sizing with buffer consumption monitoring simultaneously and project time/resource optimization. Table 1 shows all categories of literature review in this research.

Table 1

All categorizes of literature review in this research

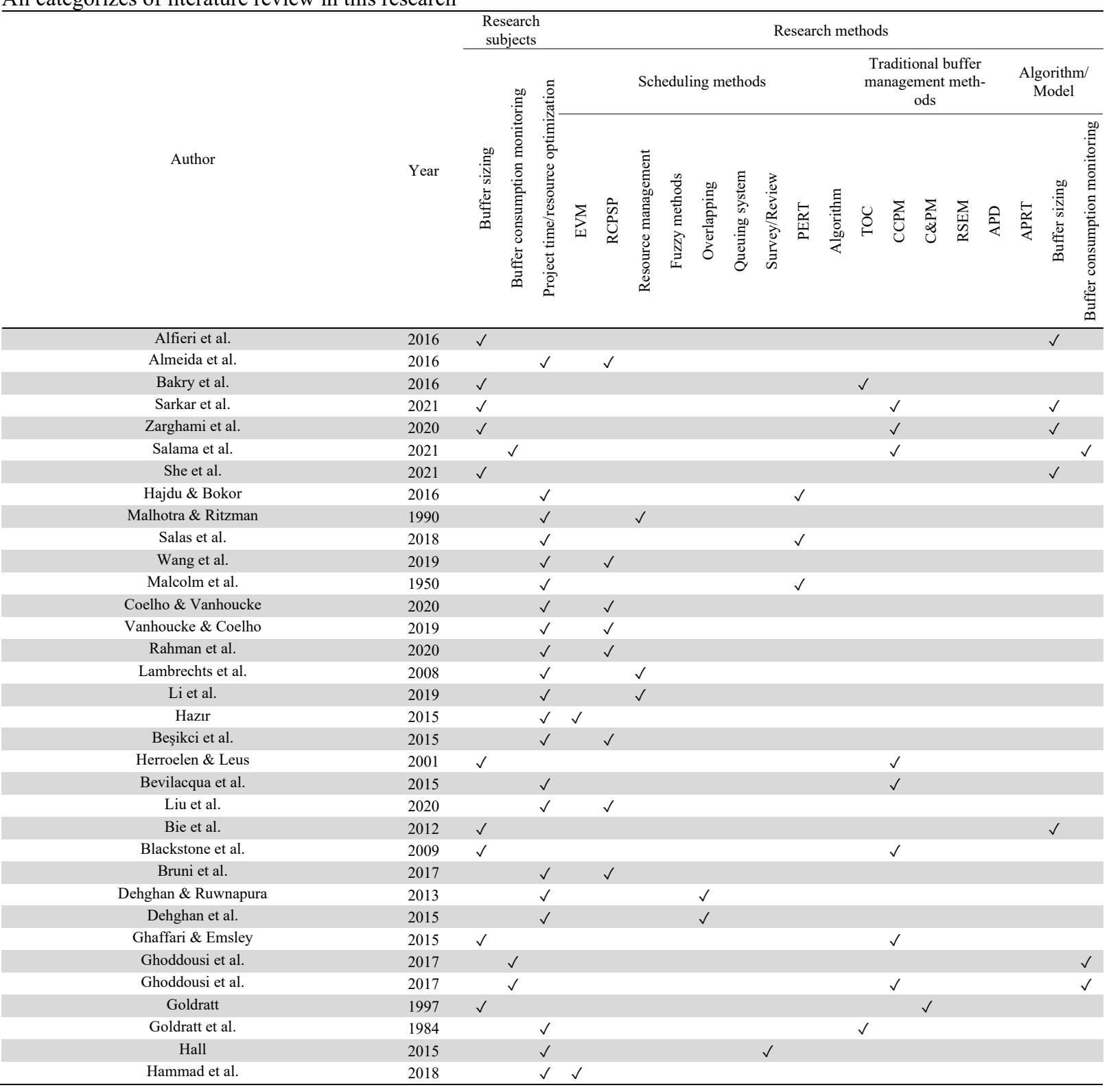


Table 1

All categorizes of literature review in this research (Continued)

\begin{tabular}{|c|c|c|c|c|c|c|c|c|c|c|c|c|c|c|c|c|c|c|c|c|c|}
\hline \multirow[b]{3}{*}{ Author } & \multirow[b]{3}{*}{ Year } & \multicolumn{3}{|c|}{$\begin{array}{c}\text { Research } \\
\text { subjects }\end{array}$} & \multicolumn{17}{|c|}{ Research methods } \\
\hline & & \multirow{2}{*}{\multicolumn{2}{|c|}{ 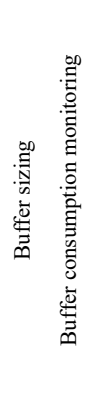 }} & \multirow{2}{*}{ 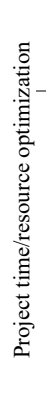 } & \multirow[b]{2}{*}{$\sum_{i=1}$} & \multirow[b]{2}{*}{$\begin{array}{l}\text { जे } \\
\text { 仓े }\end{array}$} & \multicolumn{7}{|c|}{ Scheduling methods } & \multicolumn{5}{|c|}{$\begin{array}{l}\text { Traditional buffer } \\
\text { management meth- } \\
\text { ods }\end{array}$} & \multicolumn{3}{|c|}{$\begin{array}{l}\text { Algorithm/ } \\
\text { Model }\end{array}$} \\
\hline & & & & & & & 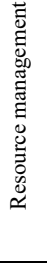 & 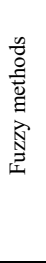 & 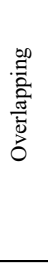 & 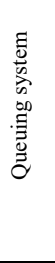 & 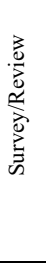 & $\frac{t}{\stackrel{4}{1}}$ & $\begin{array}{l}\text { 目 } \\
\text { 总 } \\
\frac{80}{2}\end{array}$ & 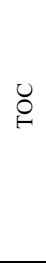 & 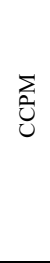 & $\sum_{\substack{\infty \\
ٍ}}^{\infty}$ & $\sum_{\substack{1\\
}}$ & 安 & 空 & 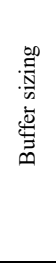 & 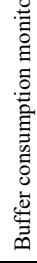 \\
\hline Hu et al. & 2015 & $\checkmark$ & & & & & & & & & & & & & & & & & & $\checkmark$ & \\
\hline Hu et al. & 2016 & & $\checkmark$ & & & & & & & & & & & & $\checkmark$ & & & & & & $\checkmark$ \\
\hline Hu et al. & 2017 & $\checkmark$ & & & & & & & & & & & & & & & & & & $\checkmark$ & \\
\hline Hu et al. & 2019 & $\checkmark$ & & & & & & & & & & & & & & & & & & $\checkmark$ & \\
\hline Kadri \& Boctor & 2018 & & & $\checkmark$ & & $\checkmark$ & & & & & & & & & & & & & & & \\
\hline Leach & 2005 & $\checkmark$ & & & & & & & & & & & & & $\checkmark$ & & & & & & \\
\hline Leyman \& Vanhoucke & 2015 & & & $\checkmark$ & & $\checkmark$ & & & & & & & & & & & & & & & \\
\hline Ma et al. & 2014 & $\checkmark$ & & & & & & & & & & & & & & & & & & $\checkmark$ & \\
\hline Ma et al. & 2015 & & & $\checkmark$ & & & & & & & & & & & $\checkmark$ & & & & & & \\
\hline Martens \& Vanhoucke & 2017 & & $\checkmark$ & & & & & & & & & & & & & & & & & & $\checkmark$ \\
\hline Mahtamtama et al. & 2018 & & $\checkmark$ & & & & & & & & & & & $\checkmark$ & & & & & & & \\
\hline Martens \& Vanhoucke & 2020 & & $\checkmark$ & & & & & & & & & & & & & & & & & & $\checkmark$ \\
\hline Naeni et al. & 2014 & & & $\checkmark$ & & & & $\checkmark$ & & & & & & & & & & & & & \\
\hline Newbold & 1998 & $\checkmark$ & & & & & & & & & & & & $\checkmark$ & & & $\checkmark$ & & & & \\
\hline Peng \& Huang & 2014 & $\checkmark$ & & & & & & & & & & & & & & & & & & $\checkmark$ & \\
\hline Peng et al. & 2015 & & & $\checkmark$ & & & & & & & & & & & $\checkmark$ & & & & & & \\
\hline Poshdar et al. & 2016 & & $\checkmark$ & & & & & & & & & & & & & & & & & & $\checkmark$ \\
\hline Iranmanesh et al. & 2016 & & $\checkmark$ & & & & & & & & & & & & & & & & & & \\
\hline Poshdar et al. & 2018 & $\checkmark$ & $\checkmark$ & & & & & & & & & & & & $\checkmark$ & & & & & $\checkmark$ & $\checkmark$ \\
\hline Rabbani et al. & 2007 & & & $\checkmark$ & & $\checkmark$ & & & & & & & & & & & & & & & \\
\hline Roghanian et al. & 2018 & $\checkmark$ & & & & & & $\checkmark$ & & & & & & & & & & & & $\checkmark$ & \\
\hline Rueda-Velasco et al. & 2017 & & & $\checkmark$ & & $\checkmark$ & & & & & & & & & & & & & & & \\
\hline Russell et al. & 2014 & $\checkmark$ & & & & & & & & & & & & & & & & & & $\checkmark$ & \\
\hline Chen et al. & 2018 & & & $\checkmark$ & & $\checkmark$ & & & & & & & & & & & & & & & \\
\hline Sarkar et al. & 2018 & $\checkmark$ & & & & & & & & & & & & & & & & & & $\checkmark$ & \\
\hline Tukel et al. & 2006 & $\checkmark$ & & & & & & & & & & & & & & & & $\checkmark$ & $\checkmark$ & & \\
\hline Vanhoucke & 2016 & $\checkmark$ & & & $\checkmark$ & & & & & & & & & & & $\checkmark$ & $\checkmark$ & $\checkmark$ & $\checkmark$ & & \\
\hline Khesal et al. & 2019 & $\checkmark$ & & & & $\checkmark$ & & & & & & & & & & & & & & & \\
\hline Zhong and Zhang & 2015 & $\checkmark$ & & & & & & & & & & & & & & & & & & & \\
\hline Woeppel & 2006 & $\checkmark$ & & & & & & & & & & & & & $\checkmark$ & & & & & & \\
\hline Zarghami et al. & 2019 & $\checkmark$ & & & & & & & & & & & & & $\checkmark$ & & & & & $\checkmark$ & \\
\hline Zhang \& Wan & 2018 & & $\checkmark$ & & & & & & & & & & & & & & & & & & $\checkmark$ \\
\hline Zhang et al. & 2015 & & & $\checkmark$ & & & & & & & & & & & $\checkmark$ & & & & & & \\
\hline Zhang et al. & 2016 & $\checkmark$ & & & & $\checkmark$ & & & & & & & & & & & & & & & \\
\hline Zhang et al. & 2017 & $\checkmark$ & & & & & & $\checkmark$ & & & & & & & & & & & & $\checkmark$ & \\
\hline Zhang et al. & 2018 & & $\checkmark$ & & & & & & & & & & & & & & & & & & $\checkmark$ \\
\hline Zohrehvandi et al. & 2017 & & & $\checkmark$ & & & & & & & & & $\checkmark$ & & & & & & & & \\
\hline Zohrehvandi et al. & 2019 & $\checkmark$ & & & & & & & & & & & & & & $\checkmark$ & $\checkmark$ & $\checkmark$ & $\checkmark$ & & \\
\hline Zohrehvandi et al. & 2019 & & & $\checkmark$ & & & & & $\checkmark$ & & & & & & & & & & & & \\
\hline Zohrehvandi et al. & 2020 & $\checkmark$ & $\checkmark$ & & & & & $\checkmark$ & $\checkmark$ & & & & & & & & & & & $\checkmark$ & $\checkmark$ \\
\hline Zohrehvandi et al. & 2020 & $\checkmark$ & $\checkmark$ & & & $\checkmark$ & & & & & & & & & & & & & & $\checkmark$ & \\
\hline Zohrehvandi et al. & 2021 & $\checkmark$ & $\checkmark$ & & & & & & & & & & & & & & & & & $\checkmark$ & $\checkmark$ \\
\hline
\end{tabular}

The rest of the paper is structured as follows: In section 2, project buffer sizing is reviewed. Project buffer consumption monitoring is reviewed in section 3 . Then, in section 4, project buffer sizing with buffer consumption monitoring simulation is reviewed. Finally, project time/resource optimization is reviewed in section 5 .

\section{Project buffer sizing}

\subsection{Proposed algorithms/models}

Bie et al. (2012) presented a technique for buffer sizing under the assumption that activities are interdependent. Ma et al. (2014) proposed a framework for using the improved CCPM method to manage construction projects. In this framework, 
they addressed two major challenges in CCPM-based construction planning: buffer sizing and multiple resource leveling. Peng and Huang (2014) suggested a useful approach to using the project critical chain method. In that study, they considered a float time in the non-critical chain as the main concern in determining feeding buffers, and thus, significantly simplified the process of using the project critical chain method. Russell et al. (2014) studied the addition of buffers to activities as a case study in construction projects. They added a time buffer to the project activities as an additional time to compensate for uncertainty, and to protect the project against tensions. Hu et al. (2015) introduced a new control procedure based on Critical Chain Scheduling and Buffer Management (CC/BM) that evaluates the probability of successful project completion relative to the cost of crashing and that determines when to expedite which activities in a cost-effective manner. Results of an experimental application of the proposed method presented its relative dominance over the currently widely adopted buffer management approach with respect to project time and cost performance. Hu et al. (2017) developed an improved framework for buffer management based on critical chain, which allowed for additional resources to be allocated if need be. Sarkar et al. (2018) focused on construction projects and developed a project management framework based on critical chains. Hu et al. (2019) presented six prioritization indices for selecting an optimal chain when more than one chain is possible. Then, they examined four production plans for rescheduling. She et al. (2021) proposed a new procedure for buffer sizing based on network decomposition, which offers logical advantages over previous ones. In this research, the size of a feeding buffer is determined from all associated noncritical chains. Then, the project buffer incorporates safety margins outside the critical chain by comparing feeding chains with their parallel critical counterparts. Table 2 lists the related works in the field of project buffer sizing.

Table 2

Project buffer sizing: Algorithms/models

\begin{tabular}{cccc}
\hline Author & Year & Research subjects & $\begin{array}{c}\text { Research methods } \\
\text { Buffer sizing } \\
\text { Buffer sizing }\end{array}$ \\
\hline Alfieri et al. & & $\checkmark$ & $\checkmark$ \\
She et al. & 2016 & $\checkmark$ & $\checkmark$ \\
Bie et al. & 2021 & $\checkmark$ & $\checkmark$ \\
Hu et al. & 2012 & $\checkmark$ & $\checkmark$ \\
Hu et al. & 2015 & $\checkmark$ & $\checkmark$ \\
Hu et al. & 2017 & $\checkmark$ & $\checkmark$ \\
Ma et al. & 2019 & $\checkmark$ & $\checkmark$ \\
Peng \& Huang & 2014 & $\checkmark$ & $\checkmark$ \\
Russell et al. & 2014 & $\checkmark$ & $\checkmark$ \\
Sarkar et al. & 2018 & $\checkmark$ & $\checkmark$ \\
\hline
\end{tabular}

\subsection{Traditional buffer management methods}

Ghaffari and Emsley (2015) studied the CCPM approach. They identified the approaches taken by researchers and suggested future research areas in this regard.

Table 3

Project buffer sizing: Traditional buffer management methods

$\begin{aligned} & \text { Research } \\ & \text { subjects }\end{aligned}$ Research methods
n

Traditional buffer management methods algorithms/models

Author

Year

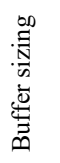

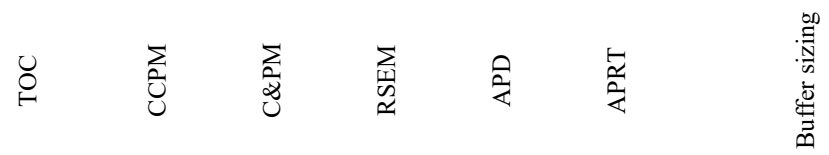

\begin{tabular}{|c|c|c|c|c|c|c|c|c|c|}
\hline Sarkar et al. & 2021 & $\checkmark$ & & $\checkmark$ & & & & & $\checkmark$ \\
\hline Zarghami et al. & 2020 & $\checkmark$ & & $\checkmark$ & & & & & $\checkmark$ \\
\hline Herroelen \& Leus & 2001 & $\checkmark$ & & $\checkmark$ & & & & & \\
\hline Blackstone et al. & 2009 & $\checkmark$ & & $\checkmark$ & & & & & \\
\hline Ghaffari \& Emsley & 2015 & $\checkmark$ & & $\checkmark$ & & & & & \\
\hline Bakry et al. & 2016 & $\checkmark$ & $\checkmark$ & & & & & & \\
\hline Goldratt & 1997 & $\checkmark$ & & . & $\checkmark$ & & & & \\
\hline Leach & 2005 & $\checkmark$ & & $\checkmark$ & & & & & \\
\hline Newbold & 1998 & $\checkmark$ & & & & $\checkmark$ & & & \\
\hline Tukel et al. & 2006 & $\checkmark$ & & & & & $\checkmark$ & $\checkmark$ & \\
\hline Vanhoucke & 2016 & $\checkmark$ & & & $\checkmark$ & $\checkmark$ & $\checkmark$ & $\checkmark$ & \\
\hline Woeppel & 2006 & $\checkmark$ & & $\checkmark$ & & & & & \\
\hline Zarghami et al. & 2019 & $\checkmark$ & & $\checkmark$ & & & & & $\checkmark$ \\
\hline Zohrehvandi \& Khalilzadeh & 2019 & $\checkmark$ & & & $\checkmark$ & $\checkmark$ & $\checkmark$ & $\checkmark$ & \\
\hline
\end{tabular}


Their main purpose was to describe the current state of research on the critical chain management method and to discover new directions for further research. The study covers 140 articles, journals, and conferences focusing on the CCPM method. Finally, 21 potential areas for critical chain management methods were recommended for future research. Vanhoucke (2016) investigated the traditional methods of buffer sizing and the way they are obtained and compared their respective results by an example. Bakry et al. (2016) introduced a buffer sizing algorithm to optimize project planning under uncertainty conditions. Zohrehvandi and Khalilzadeh (2019) integrated the APRT method with Failure Modes and Effects Analysis (FMEA), which resulted in a shorter project duration. Zarghami et al. (2019) presented a new step towards the sizing of buffers for CCPM by developing a probabilistic measure obtained through a reliability analysis of project resources. In addition, Zarghami et al. (2020) presented a new step towards the sizing of buffers for CCPM by developing a probabilistic measure obtained through a reliability analysis of project resources. In this method, buffer size was determined by assigning a scaling factor to the standard deviation of a chain. Sarkar et al. (2021) developed an enhanced CCPM framework for effective implementation of projects related to construction. The proposed framework improved buffer sizing by integrating the various uncertainties that affect construction scheduling. Table 3 shows the related works in the field of project buffer sizing: traditional buffer management methods.

\subsection{Scheduling methods}

Zhang et al. (2016) proposed a buffer sizing method based on resource tightness to better reflect the relationships between activities and improve the accuracy of project buffer sizing. They first determined resource tightness using critical quantification and resource accessibility. Then, through the design structure matrix, they analyzed the information flow between activities and the rework time resulting from information exchange and information resource tightness. Finally, the project buffer size was determined using resource tightness (both physical and information resource tightness). The results showed that the proposed method considers the effect of resource density on the project buffer, thus overcoming the shortcomings of traditional methods which consider only the physical resource tightness and ignore the information resource tightness. Zhang et al. (2017) developed a buffer sizing method based on a fuzzy resource-constrained project scheduling problem (RCPSP) to obtain an appropriate proportionality between the activity duration and the buffer size. Roghanian et al. (2018) proposed an improved critical chain approach with a fuzzy approach for project planning under uncertainty conditions. Table 4 demonstrates the related works in the field of project buffer sizing focusing on scheduling methods. Khesal et al. (2019) proposed an integrated earned value management (EVM) approach to control quality, cost, schedule and risk of projects. This study represented a new EVM framework by considering a quality control index. Particularly, some control indices and cumulative buffers defined by two proposed methods, namely the linear- and Taguchi-based methods. Zhong and Zhang (2015) addressed the RCPSP with beta distributed durations and exponential distributed resources. In this research, the resource interruptions are considered essentially to make the time buffer to compensate for the tardiness of the start time as well as to get the minimum makespan of activities in the proactive phase.

\section{Table 4}

Project buffer sizing: scheduling methods

\begin{tabular}{|c|c|c|c|c|c|c|c|c|c|c|c|}
\hline \multirow[b]{2}{*}{ Author } & \multirow[b]{2}{*}{ Year } & \multirow[b]{2}{*}{ 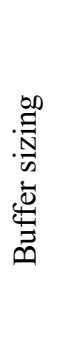 } & \multicolumn{9}{|c|}{ scheduling methods } \\
\hline & & & $\sum_{I I}$ & 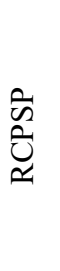 & 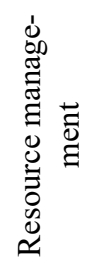 & 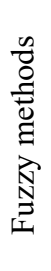 & 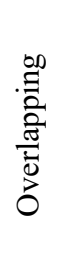 & 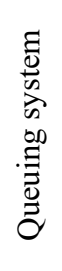 & 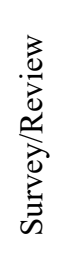 & 占 & 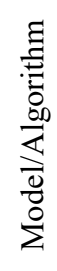 \\
\hline $\begin{array}{l}\text { Roghanian et } \\
\text { al. }\end{array}$ & 2018 & $\checkmark$ & & & & $\checkmark$ & & & & & \\
\hline Zhang et al. & 2016 & $\checkmark$ & & $\checkmark$ & & & & & & & \\
\hline Zhang et al. & 2017 & $\checkmark$ & & & & $\checkmark$ & & & & & \\
\hline Khesal et al. & 2019 & $\checkmark$ & $\checkmark$ & & & & & & & & \\
\hline $\begin{array}{l}\text { Zhong and } \\
\text { Zhang }\end{array}$ & 2015 & $\checkmark$ & & $\checkmark$ & & & & & & & \\
\hline
\end{tabular}




\section{Project buffer consumption monitoring}

\subsection{Proposed algorithms/models}

Poshdar et al. (2016) considered a probabilistic-based buffer allocation method (MPBAL) in which project planners conduct buffer sizing according to preferences. Ghoddousi et al. (2017) introduced a two-stage multi-objective buffer allocation approach for a more accurate project planning and scheduling. Martens and Vanhouck (2017) proposed a buffer controlling approach to determine the EVM of buffer allocation at various project phases. Zhang and Wan (2018) proposed an integrated buffer monitoring method. In their research, the prediction model based on the grey neural network was established, and the follow-up buffer consumption was predicted quantitatively according to the past and present performance data at the project monitoring points. Then, considering the relationship between the buffered consumed and the follow-up buffer consumption, a buffer integrated monitoring system was formed based on the integrated quantitative analysis on the buffer consumed and the subsequent trend information at each monitoring point. A buffer control model was presented by Zhang et al. (2018) which functioned in accordance with respective circumstances of different project phases. Martens and Vanhoucke (2020) improved the accuracy of project time forecasting by extending exponential smoothing for project time forecasting using EVM and earned duration management with the integration of corrective actions that are taken during project progress. According to the findings, the new heuristic was significantly useful in developing effective solutions within small CPU times. Table 5 lists the related works in the field of project buffer consumption monitoring: proposed algorithms/models.

Table 5

Project buffer consumption monitoring: Proposed algorithms/models

\begin{tabular}{|c|c|c|c|}
\hline \multirow[b]{3}{*}{ Author } & \multirow[b]{3}{*}{ Year } & $\begin{array}{l}\text { Research sub- } \\
\text { jects }\end{array}$ & Research methods \\
\hline & & \multirow{2}{*}{ 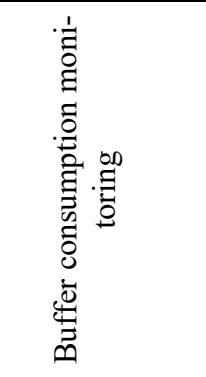 } & Proposed algorithms/models \\
\hline & & & 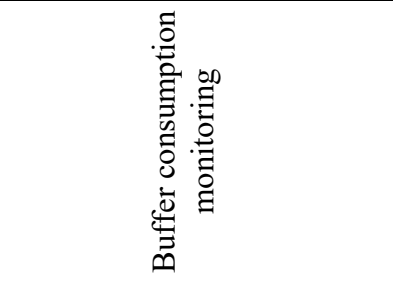 \\
\hline Ghoddousi et al. & 2017 & $\checkmark$ & $\checkmark$ \\
\hline Martens \& Vanhoucke & 2017 & $\checkmark$ & $\checkmark$ \\
\hline Martens \& Vanhoucke & 2020 & $\checkmark$ & $\checkmark$ \\
\hline Poshdar et al. & 2016 & $\checkmark$ & $\checkmark$ \\
\hline Zhang \& Wan & 2018 & $\checkmark$ & $\checkmark$ \\
\hline Zhang et al. & 2018 & $\checkmark$ & $\checkmark$ \\
\hline
\end{tabular}

\subsection{Traditional buffer management methods}

Hu et al. (2016) proposed a new project schedule monitoring framework by introducing the activity crucial index. A buffer sizing method was introduced by Ghoddousi et al. (2017), aiming at maximizing the efficiency of the project schedule. Salama et al. (2021) presented a new method for project tracking and control of integrated offsite and onsite activities in modular construction considering practical characteristics associated with this type of construction. Mahtamtama et al. (2018) proposed a dashboard for inventory monitoring that could perform cycle counting whilst also implementing a specific concept in TOC which is Buffer Time Management, this concept applies buffers on a certain period to each item inside the warehouse. Iranmanesh et al. (2016) research proposed an innovative buffer management method based on optimizing attributes to improve the efficiency of buffer management and optimize the estimation accuracy of a project buffer. The Monte Carlo simulation results showed that the buffer obtained using this method is smaller than the cut and paste method, but larger than the root square error method. Table 6 shows the related works in the field of project buffer consumption monitoring: traditional buffer management methods. 
Table 6

Project buffer consumption monitoring: Traditional buffer management methods

\begin{tabular}{|c|c|c|c|c|c|c|c|c|c|}
\hline \multirow[b]{3}{*}{ Author } & \multirow[b]{3}{*}{ Year } & \multirow{3}{*}{ 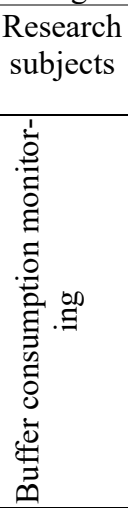 } & \multicolumn{7}{|c|}{ Research methods } \\
\hline & & & \multicolumn{6}{|c|}{ Traditional buffer management methods } & \multirow{2}{*}{ 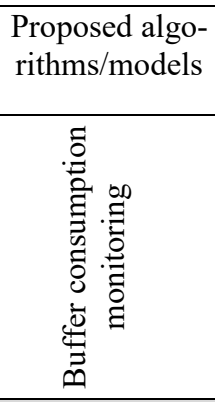 } \\
\hline & & & $\stackrel{\circlearrowright}{\bigodot}$ & $\sum_{\circlearrowright}$ & 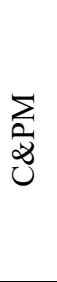 & $\sum_{\substack{\underline{1} \\
\approx}}$ & Qे & 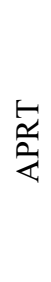 & \\
\hline Salama et al. & 2021 & $\checkmark$ & & $\checkmark$ & & & & & $\checkmark$ \\
\hline Ghoddousi et al. & 2017 & $\checkmark$ & & $\checkmark$ & & & & & $\checkmark$ \\
\hline Hu et al. & 2016 & $\checkmark$ & & $\checkmark$ & & & & & $\checkmark$ \\
\hline Mahtamtama et al. & 2018 & $\checkmark$ & $\checkmark$ & & & & & & \\
\hline Iranmanesh et al. & 2016 & $\checkmark$ & & $\checkmark$ & & & & & \\
\hline
\end{tabular}

\section{Project buffer sizing with buffer consumption monitoring}

\subsection{Proposed algorithms/models and scheduling methods}

Poshdar et al. (2018) proposed a Multi-objective Probabilistic-Based Buffer Allocation method based on a goal-seeking optimization approach that uses a visual presentation of the mathematical optimization results to involve the preference of the project decision-makers in the final solution. Zohrehvandi et al. (2020) introduced a heuristic algorithm to determine the sizes of project buffers and feeding buffers as well as dynamically control buffer consumption, named as Fuzzy Overlapping Buffer Management Algorithm (FOBMA). In the research, the pentagonal fuzzy numbers were used to determine the appropriate amount of project activity resources. Also, an overlapping method was applied to obtain more realist activity durations. Another shortcoming of those methods is the lack of control over the consumption of buffers (Zohrehvandi et al., 2020). In this research, buffer consumption is controlled by using a dynamic method.

Table 7

Project buffer sizing with buffer consumption monitoring: Proposed algorithms/models and scheduling methods Research sub-
jects Research methods

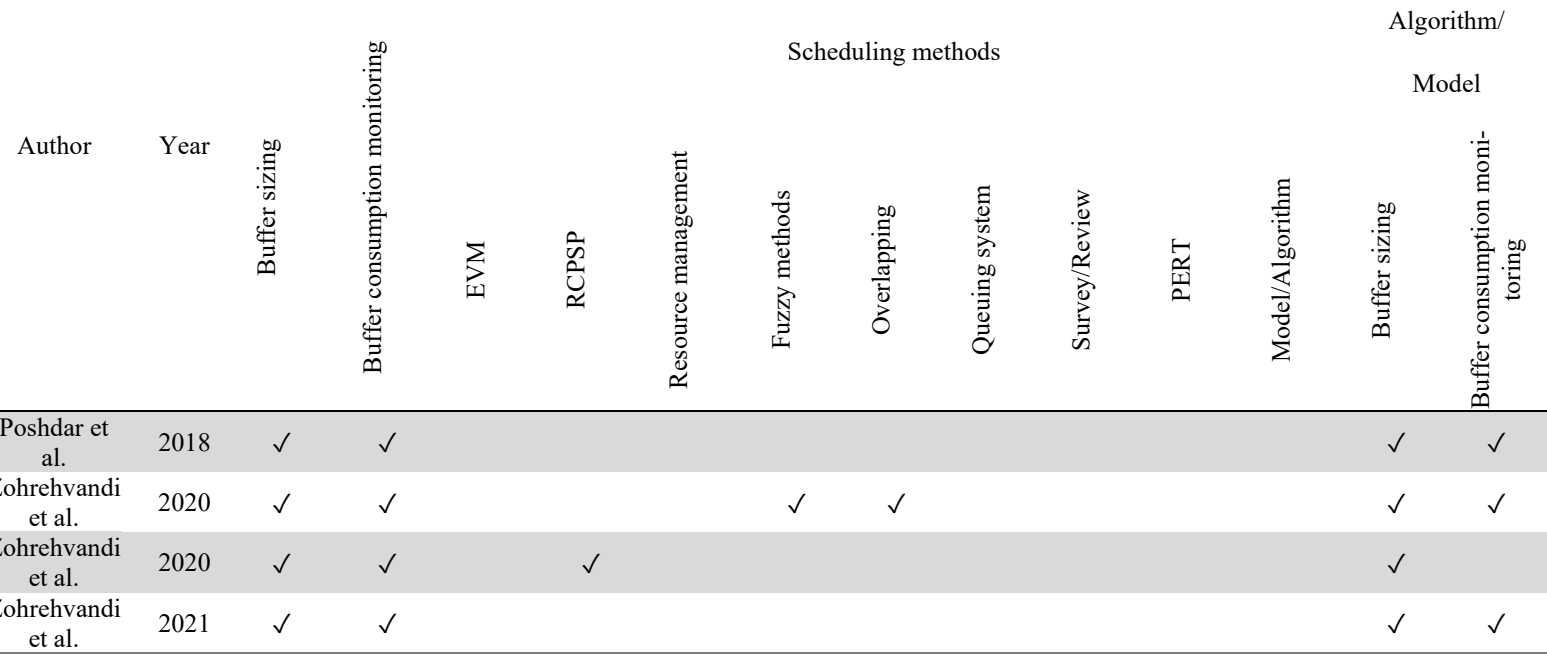


Due to varying circumstances in different phases of the project in terms of the duration of each phase, the amounts of activities' resources, and the complexity of the activities network, it is essential that buffer consumption be controlled dynamically. In this way, the amount of buffers which remains unconsumed in each phase of the project, will be transferred to the next phase. In addition, Zohrehvandi et al. (2021) proposed a project time optimization algorithm for calculating project buffer and feeding buffers as well as dynamic controlling of buffer consumption in different phases of a wind power plant project for finding a more realistic project duration. The author is currently working deeply on this topic and has several articles under review that will develop this topic. Table 7 demonstrates the related works in the field of project buffer sizing with buffer consumption monitoring: proposed algorithms/models and scheduling methods.

\section{Project time/resource optimization}

\subsection{Traditional buffer management methods}

Bevilacqua et al. (2015) examined a real problem consisting of a multi-objective optimization of planning a project's activities by taking resource constraints and prioritization into account. They used the CCPM method in this study. A scenariobased optimization method based on CCPM was suggested by Ma et al. (2015) with the aim of improving the robustness of schedules in construction projects. Peng et al. (2015) evaluated prioritization of critical chain scheduling issues in different execution modes. The results showed that by including the prioritization, the least number of resources was used in the project. Zhang et al. (2015) proposed a new approach for the CCPM method by considering an information-based relationship amongst project activities. Table 8 lists the related works in the field of project time/resource optimization: traditional buffer management methods.

Table 8

Project time/resource optimization: Traditional buffer management methods

\begin{tabular}{|c|c|c|c|c|c|c|c|c|}
\hline \multirow{3}{*}{ Author } & \multirow{3}{*}{ Year } & \multirow{3}{*}{$\begin{array}{l}\text { Research } \\
\text { subjects }\end{array}$} & \multicolumn{6}{|c|}{ Research methods } \\
\hline & & & \multicolumn{6}{|c|}{ Traditional buffer management methods } \\
\hline & & & $\stackrel{\circlearrowright}{\ominus}$ & 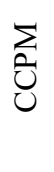 & $\sum_{\substack{\infty \\
ٍ}}$ & 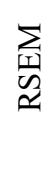 & $\stackrel{2}{\gtrless}$ & 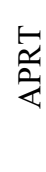 \\
\hline Bevilacqua et al. & 2015 & $\checkmark$ & & $\checkmark$ & & & & \\
\hline Goldratt et al. & 1984 & $\checkmark$ & $\checkmark$ & & & & & \\
\hline Ma et al. & 2015 & $\checkmark$ & & $\checkmark$ & & & & \\
\hline Peng et al. & 2015 & $\checkmark$ & & $\sqrt{ }$ & & & & \\
\hline Zhang et al. & 2015 & $\checkmark$ & & $\checkmark$ & & & & \\
\hline
\end{tabular}

\subsection{Scheduling methods}

The PERT method was first introduced by the US Navy for a large and complex submarine project (Salas-Morera et al., 2018). The PERT method is the most extensive technique for project planning, scheduling, and controlling, and a method for project evaluation and review (Malcolm et al., 1959). One assumption is the Beta distribution with a three-point estimate: optimistic (a), most probable (m), and pessimistic (b), and the mean $=$. The use of several distributions with other parameter estimates has been proposed (Hajdu and Bokor 2016). Zhao et al. (2020) solved the resource conflict problems by a twostage approach combined with a feeding buffer for rescheduling. Beşikci et al. (2015) introduced a multi-project planning environment which included several projects with specific dates. They presented three scheduling problems to explore this multi-project environment. In their research, they integrated this multi-project environment as one model, and presented it as a resource portfolio problem. Leyman and Vanhoucke (2015) introduced a scheduling approach that improved the project's net present value. Almeida et al. (2016) investigated one of the latest approaches for project scheduling under resource constraints. Rueda-Velasco et al. (2017) presented an algorithm for multi-project scheduling with respect to dynamic resource allocation. Bruni et al. (2017) proposed an RCPSP with uncertain activity durations. Kadri and Boctor (2018) presented an RCPSP with transferable times. Kadri and Boctor (2018) included transfer times in their proposed resourceconstrained project scheduling problem. Chen et al. (2018) examined the performance of 17 priority rule-based heuristics and the justification technique on the stochastic RCPSP. Vanhoucke and Coelho (2019) presented a new solution algorithm to solve the RCPSP with activity splitting and setup times. Wang et al. (2019) considered an RCPSP with a single shared resource. Liu et al. (2020) investigated an energy-efficient integration of process planning and scheduling based on RCPSP. Rahman et al. (2020) proposed an algorithm based on genetic algorithms to solve a resource-constrained project planning problem. They implemented the proposed algorithm in the critical path of the project. It was a heuristic algorithm based on 
the critical path. Coelho and Vanhoucke (2020) created insight and understanding into what makes an RCPSP instance hard, and proposed a new dataset that consists of a small set of instances that are impossible to solve with the algorithms currently existing in the literature.

Table 9

Project time/resource optimization: scheduling methods

\begin{tabular}{|c|c|c|c|c|c|c|c|c|c|c|c|}
\hline \multirow[b]{3}{*}{ Author } & \multirow[b]{3}{*}{ Year } & \multirow{3}{*}{ 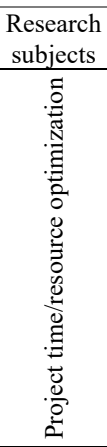 } & \multicolumn{9}{|c|}{ Research methods } \\
\hline & & & \multicolumn{9}{|c|}{ scheduling methods } \\
\hline & & & $\sum_{I=1}^{S}$ & $\begin{array}{l}\text { के } \\
\text { टे } \\
\approx\end{array}$ & 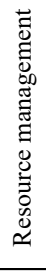 & 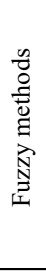 & 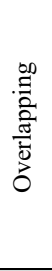 & 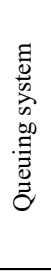 & 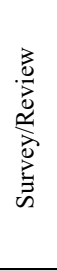 & $\underset{\mathfrak{r}}{\stackrel{t}{2}}$ & 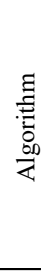 \\
\hline Almeida et al. & 2016 & $\checkmark$ & & $\checkmark$ & & & & & & & \\
\hline Hajdu \& Bokor & 2016 & $\checkmark$ & & & & & & & & $\checkmark$ & \\
\hline Salas et al. & 2018 & $\checkmark$ & & & & & & & & $\checkmark$ & \\
\hline Wang et al. & 2019 & $\checkmark$ & & $\checkmark$ & & & & & & & \\
\hline Malcolm et al. & 1950 & $\checkmark$ & & & & & & & & $\checkmark$ & \\
\hline Coelho \& Vanhoucke & 2020 & $\checkmark$ & & $\checkmark$ & & & & & & & \\
\hline Vanhoucke \& Coelho & 2019 & $\checkmark$ & & $\checkmark$ & & & & & & & \\
\hline Rahman et al. & 2020 & $\checkmark$ & & $\checkmark$ & & & & & & & \\
\hline Li et al. & 2019 & $\checkmark$ & & & $\checkmark$ & & & & & & \\
\hline Hazır & 2015 & $\checkmark$ & $\checkmark$ & & & & & & & & \\
\hline Beşikci et al. & 2015 & $\checkmark$ & & $\checkmark$ & & & & & & & \\
\hline Liu et al. & 2020 & $\checkmark$ & & $\checkmark$ & & & & & & & \\
\hline Bruni et al. & 2017 & $\checkmark$ & & $\checkmark$ & & & & & & & \\
\hline Dehghan \& Ruwnapura & 2013 & $\checkmark$ & & & & & $\checkmark$ & & & & \\
\hline Dehghan et al. & 2015 & $\checkmark$ & & & & & $\checkmark$ & & & & \\
\hline Hall & 2015 & $\checkmark$ & & & & & & & $\checkmark$ & & \\
\hline Hammad et al. & 2018 & $\checkmark$ & $\checkmark$ & & & & & & & & \\
\hline Kadri \& Boctor & 2018 & $\checkmark$ & & $\checkmark$ & & & & & & & \\
\hline Leyman \& Vanhoucke & 2015 & $\checkmark$ & & $\checkmark$ & & & & & & & \\
\hline Naeni et al. & 2014 & $\checkmark$ & $\checkmark$ & & & $\checkmark$ & & & & & \\
\hline Rabbani et al. & 2007 & $\checkmark$ & & $\checkmark$ & & & & & & & \\
\hline Rueda-Velasco et al. & 2017 & $\checkmark$ & & $\checkmark$ & & & & & & & \\
\hline Chen et al. & 2018 & $\checkmark$ & & $\checkmark$ & & & & & & & \\
\hline Zohrehvandi et al. & 2017 & $\checkmark$ & & & & & & & & & $\checkmark$ \\
\hline Zohrehvandi et al. & 2019 & $\checkmark$ & & & & & $\checkmark$ & & & & \\
\hline
\end{tabular}

Project planning and control are critical functions in project management. These functions involve a host of decision problems for scheduling projects, identifying and reporting the status of the project, comparing it with the baseline plan, analyzing the deviations, detecting out-of-control situations, and taking appropriate corrective actions (Hazir 2015). Hammad et al. (2018) presented a new framework for estimating, allocating, and managing planning probabilities using the TOC and the obtained value. Naeni et al. (2014) presented a new fuzzy-based earned value model with the advantage of developing and analyzing the earned value indices, and the time and the cost estimates at completion under uncertainty. Dehghan and Ruwnapura (2013) introduced an algorithm based on overlap among activities to optimize time and cost in activities and projects. Dehghan et al. (2015) improved an algorithm by using the activities overlapping method and utilizing genetic algorithms to optimize durations of projects' activities. Zohrehvandi et al. (2019) introduced a reconfigurable model that is a combination of a schedule model and a queuing system $\mathrm{M} / \mathrm{M} / \mathrm{m} / \mathrm{K}$ to reduce the duration of the wind turbine construction project closure phase and reduce the project documentation waiting time in the queue. Also, Zohrehvandi et al. (2017) presented an algorithm for sequencing and scheduling of the activities in the project completion phase and reduced the duration of the phase. Table 9 shows the related works in the field of project time/resource optimization: scheduling methods. 


\section{Conclusion}

The purpose of this study was to discuss the state of the art on models and methods for project buffer management and time optimization in construction projects and manufacturing industries. This research investigated the literature from project buffer sizing, project buffer consumption monitoring and project time/resource optimization perspectives with respect to traditional buffer management methods, algorithms/models and scheduling methods. According to the literature review, research carried out so far in the field of project buffer management and time optimization generally concentrated on traditional buffer management methods. Although, in some cases, scheduling methods have been employed to manage the buffer of a project, most of the research have used traditional methods of buffer management. The focus of this study has been on introduction and application of hybrid algorithms and models of simultaneous Buffer sizing and Buffer consumption. Scholars and researchers can study each of the mentioned papers and see the changing trend of the subjects from the scratch so that they can perceive the need for developing new algorithms and models in project buffer management and time optimization. For this purpose, for each area the authors tried to have a quick review on early works and for each classification some of the prominent works in the literature have been introduced so that the interested readers can refer and find other related papers to study.

\section{References}

Alfieri, A., Matta, A., \& Pastore, E. (2016). A column generation algorithm for the Buffer Allocation Problem approximated by the Time Buffer concept. IFAC-PapersOnLine, 49(12), 739-744, https://doi.org/10.1016/j.ifacol.2016.07.862.

Almeida, B. F., Correia, I., \& Saldanha-da-Gama, F. (2016). Priority-based heuristics for the multi-skill resource constrained project scheduling problem. Expert Systems with Applications, 57, 91-103, https://doi.org/10.1016/j.eswa.2016.03.017.

Bakry, I., Moselhi, O., \& Zayed, T. (2016). Optimized scheduling and buffering of repetitive construction projects under uncertainty. Engineering, Construction and Architectural Management, 23(6), 782-800, https://doi.org/10.1108/ECAM-05-2014$\underline{0069}$.

Beşikci, U., Bilge, Ü., \& Ulusoy, G. (2015). Multi-mode resource constrained multi-project scheduling and resource portfolio problem. European Journal of Operational Research, 240(1), 22-31.

Bevilacqua, M., Ciarapica, F. E., Mazzuto, G., \& Paciarotti, C. (2015). Robust multi-criteria project scheduling in plant engineering and construction. In Handbook on Project Management and Scheduling Vol. 2 (pp. 1291-1305). Springer, Cham.

Bie, L., Cui, N., \& Zhang, X. (2012). Buffer sizing approach with dependence assumption between activities in critical chain scheduling. International Journal of Production Research, 50(24), 7343-7356, https://doi.org/10.1080/00207543.2011.649096.

Blackstone, J.H., Cox, J.F., and Schleier, J.G. (2009). A tutorial on project management from a theory of constraints perspective. International Journal of Production Research, 47 (24), 7029-7046, https://doi.org/10.1080/00207540802392551.

Bruni, M. E., Pugliese, L. D. P., Beraldi, P., \& Guerriero, F. (2017). An adjustable robust optimization model for the resourceconstrained project scheduling problem with uncertain activity durations. Omega, 71, 66-84, https://doi.org/10.1016/j.omega.2016.09.009.

Chen, Z., Demeulemeester, E., Bai, S., \& Guo, Y. (2018). Efficient priority rules for the stochastic resource-constrained project scheduling problem. European Journal of Operational Research, 270(3), 957-967, https://doi.org/10.1016/j.ejor.2018.04.025.

Coelho, J., \& Vanhoucke, M. (2020). Going to the core of hard resource-constrained project scheduling instances. Computers \& Operations Research, 121, 104976, https://doi.org/10.1016/j.cor.2020.104976.

Dehghan, R., \& Ruwnapura, J. Y. (2013). Model of trade-off between overlapping and rework of design activities. Journal of Construction Engineering and Management, 140(2), 04013043, https://doi.org/10.1061/(ASCE)CO.1943-7862.0000786.

Dehghan, R., Hazini, K., \& Ruwanpura, J. (2015). Optimization of overlapping activities in the design phase of construction projects. Automation in Construction, 59, 81-95, https://doi.org/10.1016/j.autcon.2015.08.004.

E.M. Goldratt, Critical Chain, North River Press, New York, 1997

Ghaffari, M., \& Emsley, M. W. (2015). Current status and future potential of the research on Critical Chain Project Management. Surveys in Operations Research and Management Science, 20(2), 43-54.

Ghoddousi, P., Ansari, R., \& Makui, A. (2017). A risk-oriented buffer allocation model based on critical chain project management. KSCE Journal of Civil Engineering, 21(5), 1536-1548, https://doi.org/10.1007/s12205-016-0039-y.

Ghoddousi, P., Ansari, R., \& Makui, A. (2017). An improved robust buffer allocation method for the project scheduling problem. Engineering Optimization, 49(4), 718-731, https://doi.org/10.1080/0305215X.2016.1206534.

Goldratt, E. M., \& Cox, J. (1984). The goal: excellence in manufacturing. North River Press.

Hajdu, M., \& Bokor, O. (2016). Sensitivity analysis in PERT networks: Does activity duration distribution matter?. Automation in Construction, 65, 1-8.

Hall, N. G. (2015). Further research opportunities in project management. In Handbook on Project Management and Scheduling Vol. 2 (pp. 945-970). Springer, Cham, https://doi.org/10.1007/978-3-319-05915-0 13.

Hammad, M. W., Abbasi, A., \& Ryan, M. J. (2018). Developing a Novel Framework to Manage Schedule Contingency Using Theory of Constraints and Earned Schedule Method. Journal of Construction Engineering and Management, 144(4), 04018011.

Hazır, Ö. (2015). A review of analytical models, approaches and decision support tools in project monitoring and control. International Journal of Project Management, 33(4), 808-815.

Herroelen, W., \& Leus, R. (2001). On the merits and pitfalls of critical chain scheduling. Journal of operations management, 19(5), 559-577, https://doi.org/10.1016/S0272-6963(01)00054-7. 
Hu, X., Cui, N., \& Demeulemeester, E. (2015). Effective expediting to improve project due date and cost performance through buffer management. International Journal of Production Research, 53(5), 1460-1471.

$\mathrm{Hu}$, X., Cui, N., Demeulemeester, E., \& Bie, L. (2016). Incorporation of activity sensitivity measures into buffer management to manage project schedule risk. European Journal of Operational Research, 249(2), 717-727, https://doi.org/10.1016/j.ejor.2015.08.066.

Hu, X., Demeulemeester, E., Cui, N., Wang, J., \& Tian, W. (2017). Improved critical chain buffer management framework considering resource costs and schedule stability. Flexible Services and Manufacturing Journal, 29(2), 159-183, https://doi.org/10.1007/s10696-016-9241-y.

Hu, X., Wang, J., \& Leng, K. (2019). The interaction between critical chain sequencing, buffer sizing, and reactive actions in a CC/BM framework. Asia-Pacific Journal of Operational Research, 36(03), 1950010.

Iranmanesh, H., Mansourian, F., \& Kouchaki, S. (2016). Critical chain scheduling: a new approach for feeding buffer sizing. International Journal of Operational Research, 25(1), 114-130.

Kadri, R. L., \& Boctor, F. F. 2018. An efficient genetic algorithm to solve the resource-constrained project scheduling problem with transfer times: The single mode case. European Journal of Operational Research, 265(2), 454-462, https://doi.org/10.1016/j.ejor.2017.07.027.

Khesal, T., Saghaei, A., Khalilzadeh, M., Galankashi, M. R., \& Soltani, R. (2019). Integrated cost, quality, risk and schedule control through earned value management (EVM). Journal of Engineering, Design and Technology.

Leach, L.P. (2005). Critical chain project management. 2nd ed. London: Artech House Inc.

Leyman, P., \& Vanhoucke, M. (2015). A new scheduling technique for the resource-constrained project scheduling problem with discounted cash flows. International Journal of Production Research, 53(9), 2771-2786, https://doi.org/10.1080/00207543.2014.980463.

Li, H., Wang, M., \& Dong, X. 2019. Resource Leveling in Projects with Stochastic Minimum Time Lags. Journal of Construction Engineering and Management, 145(4), 04019015, https://doi.org/10.1061/(ASCE)CO.1943-7862.0001635.

Liu, N., Zhang, Y. F., \& Lu, W. F. 2020. Energy-efficient integration of process planning and scheduling in discrete parts manufacturing with a heuristic-based two-stage approach. The International Journal of Advanced Manufacturing Technology, 106(5), 2415-2432, https://doi.org/10.1007/s00170-019-04776-x.

Ma, G., Gu, L., \& Li, N. 2015. Scenario-based proactive robust optimization for critical-chain project scheduling. Journal of Construction Engineering and Management, 141(10), 04015030, https://doi.org/10.1061/(ASCE)CO.1943-7862.0001003.

Ma, G., Wang, A., Li, N., Gu, L., \& Ai, Q. (2014). Improved critical chain project management framework for scheduling construction projects. Journal of Construction Engineering and Management, 140(12), 04014055.

Mahtamtama, E., Ridwan, A. Y., \& Santosa, B. (2018, October). Development Of Cycle Counting Monitoring Dashboard With Buffer Time Management For Cocoa Company. In 2018 12th International Conference on Telecommunication Systems, Services, and Applications (TSSA) (pp. 1-5). IEEE.

Malcolm D.G., Roseboom J.H., and Clark C.E., (1959), Application of a technique of research and development program evaluation. Operations Research, $7,646-669$, https://doi.org/10.1287/opre.7.5.646.

Martens, A., \& Vanhoucke, M. (2020). Integrating Corrective Actions in Project Time Forecasting Using Exponential Smoothing. Journal of Management in Engineering, 36(5), 04020044, https://doi.org/10.1061/(ASCE)ME.1943-5479.0000806.

Martens, A., \& Vanhoucke, M. 2017. A buffer control method for top-down project control. European Journal of Operational Research, 262(1), 274-286, https://doi.org/10.1016/j.ejor.2017.03.034.

Naeni, L. M., Shadrokh, S., \& Salehipour, A. (2014). A fuzzy approach for the earned value management. International Journal of Project Management, 32(4), 709-716.

Newbold, R. C. (1998). Project management in the fast lane: applying the theory of constraints. CRC Press.

Peng, W., \& Huang, M. (2014). A critical chain project scheduling method based on a differential evolution algorithm. International Journal of Production Research, 52(13), 3940-3949.

Peng, W., Huang, M., \& Yongping, H. (2015). A multi-mode critical chain scheduling method based on priority rules. Production Planning \& Control, 26(12), 1011-1024.

Poshdar, M., González, V. A., Raftery, G. M., Orozco, F., \& Cabrera-Guerrero, G. G. (2018). A multi-objective probabilisticbased method to determine optimum allocation of time buffer in construction schedules. Automation in Construction, 92, 4658.

Poshdar, M., González, V. A., Raftery, G. M., Orozco, F., Romeo, J. S., \& Forcael, E. 2016. A probabilistic-based method to determine optimum size of project buffer in construction schedules. Journal of Construction Engineering and Management, 142(10), 04016046, https://doi.org/10.1061/(ASCE)CO.1943-7862.0001158.

Rabbani, M., et al., 2007. A new heuristic for resource-constrained project scheduling in stochastic networks using critical chain concept. European Journal of Operational Research, 176 (2), 794-808, https://doi.org/10.1016/j.ejor.2005.09.018.

Rahman, H. F., Chakrabortty, R. K., \& Ryan, M. J. (2020). Memetic algorithm for solving resource constrained project scheduling problems. Automation in Construction, 111, 103052.

Roghanian, E., Alipour, M., \& Rezaei, M. (2018). An improved fuzzy critical chain approach in order to face uncertainty in project scheduling. International Journal of Construction Management, 18(1), 1-13, https://doi.org/10.1080/15623599.2016.1225327.

Rueda-Velasco, F. J., Cubaque, C. E., \& Latorre, J. M. I. (2017, September). Project Scheduling with Dynamic Resource Allocation in a Multi-project Environment. Case: Bogotá Electricity Distributor. In Workshop on Engineering Applications (pp. 589-600). Springer, Cham.

Russell, M. M., Liu, M., Howell, G., \& Hsiang, S. M. (2014). Case studies of the allocation and reduction of time buffer through use of the last planner system. Journal of Construction Engineering and Management, 141(2), 04014068.

Salama, T., Salah, A., \& Moselhi, O. (2021). Integrating critical chain project management with last planner system for linear scheduling of modular construction. Construction Innovation. 
Salas-Morera, L., Arauzo-Azofra, A., García-Hernández, L., Palomo-Romero, J. M., \& Ayuso-Muñoz, J. L. (2018). New Approach to the Distribution of Project Completion Time in PERT Networks. Journal of Construction Engineering and Management, 144(10), 04018094.

Sarkar, D., Jha, K. N., \& Patel, S. (2021). Critical chain project management for a highway construction project with a focus on theory of constraints. International Journal of Construction Management, 21(2), 194-207.

Sarkar, D., Jha, K. N., \& Patel, S. 2018. Critical chain project management for a highway construction project with a focus on theory of constraints. International Journal of Construction Management, 1-14, https://doi.org/10.1080/15623599.2018.1512031.

She, B., Chen, B., \& Hall, N. G. (2021). Buffer sizing in critical chain project management by network decomposition. Omega, 102, 102382.

Tukel, O. I., Rom, W. O., \& Eksioglu, S. D. (2006). An investigation of buffer sizing techniques in critical chain scheduling. European Journal of Operational Research, 172(2), 401-416, https://doi.org/10.1016/j.ejor.2004.10.019.

Vanhoucke, M. (2016). Buffer management. In Integrated Project Management Sourcebook (pp. 155-193). Springer, Cham, https://doi.org/10.1007/978-3-319-27373-0.

Vanhoucke, M., \& Coelho, J. 2019. Resource-constrained project scheduling with activity splitting and setup times. Computers \& Operations Research, 109, 230-249, https://doi.org/10.1016/i.cor.2019.05.004.

Wang, Q., Liu, C., \& Zheng, L. (2019). A column-generation-based algorithm for a resource-constrained project scheduling problem with a fractional shared resource. Engineering Optimization, 1-19, https://doi.org/10.1080/0305215X.2019.1610946.

Woeppel, M.J., 2006. Projects in less time: a synopsis of critical chain. Plano, Texas: Pinnacle Strategies Pub.

Zarghami, S. A., Gunawan, I., Corral de Zubielqui, G., \& Baroudi, B. (2020). Incorporation of resource reliability into critical chain project management buffer sizing. International Journal of Production Research, 58(20), 6130-6144.

Zarghami, S. A., Gunawan, I., Corral de Zubielqui, G., \& Baroudi, B. (2019). Incorporation of resource reliability into critical chain project management buffer sizing. International Journal of Production Research, 1-15, https://doi.org/10.1080/00207543.2019.1667041.

Zhang, J., \& Wan, D. (2018). Integrated buffer monitoring and control based on grey neural network. Journal of the Operational Research Society, 1-14.

Zhang, J., Jia, S., \& Diaz, E. 2018. Dynamic monitoring and control of a critical chain project based on phase buffer allocation. Journal of the Operational Research Society, 1-12, https://doi.org/10.1080/01605682.2017.1415641.

Zhang, J., Song, X., \& Díaz, E. (2016). Project buffer sizing of a critical chain based on comprehensive resource tightness. European Journal of Operational Research, 248(1), 174-182.

Zhang, J., Song, X., \& Díaz, E. 2017. Critical chain project buffer sizing based on resource constraints. International Journal of Production Research, 55(3), 671-683, https://doi.org/10.1080/00207543.2016.1200151.

Zhang, J., Song, X., Chen, H., \& Shi, R. (2015). Optimisation of critical chain sequencing based on activities' information flow interactions. International Journal of Production Research, 53(20), 6231-6241.

Zhao, Y., Cui, N., \& Tian, W. (2020). A two-stage approach for the critical chain project rescheduling. Annals of Operations Research, 285(1), 67-95, https://doi.org/10.1007/s10479-019-03347-3.

Zhong, X., \& Zhang, Z. (2015). Proactive Scheduling Procedures for RCPSP with Beta Distributed Durations and Exponential Distributed Resources. In Proceedings of the Ninth International Conference on Management Science and Engineering Management (pp. 855-867). Springer, Berlin, Heidelberg.

Zohrehvandi, S., \& Khalilzadeh, M. 2019. APRT-FMEA buffer sizing method in scheduling of a wind farm construction project. Engineering, Construction and Architectural Management, https://doi.org/10.1108/ECAM-04-2018-0161.

Zohrehvandi, S., Khalilzadeh, M., Amiri, M., \& Shadrokh, S. (2020). A heuristic buffer sizing algorithm for implementing a renewable energy project. Automation in Construction, 117, 103267.

Zohrehvandi, S., Khalilzadeh, M., Hajizadeh, M., \& Cheraghi, E. (2017). Planning project closure phase in combined cycle power plant projects. Procedia Computer Science, 121, 274-281, https://doi.org/10.1016/j.procs.2017.11.038.

Zohrehvandi, S., Vanhoucke, M., Soltani, R., \& Javadi, M. (2019). A reconfigurable model for implementation in the closing phase of a wind turbines project construction. Engineering, Construction and Architectural Management, 27(2), 502-524. https://doi.org/10.1108/ECAM-01-2019-0065.

Zohrehvandi, S., Khalilzadeh, M., Amiri, M. and Shadrokh, S. (2021), "Project buffer sizing and dynamic buffer consumption algorithm in power generation construction", Engineering, Construction and Architectural Management, Vol. ahead-of-print No. ahead-of-print, https://doi.org/10.1108/ECAM-08-2020-0605.

Zohrehvandi, S., Vanhoucke, M. and Khalilzadeh, M. (2020), "A project buffer and resource management model in energy sector; a case study in construction of a wind farm project", International Journal of Energy Sector Management, 14(6), 11231142. https://doi.org/10.1108/IJESM-10-2019-0025.

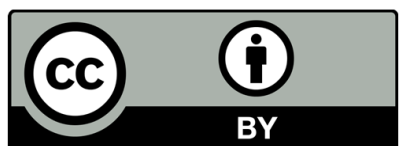

(C) 2022 by the authors; licensee Growing Science, Canada. This is an open access article distributed under the terms and conditions of the Creative Commons Attribution (CC-BY) license (http://creativecommons.org/licenses/by/4.0/). 